\title{
Practical Integration Approach and Whole Building Energy Simulation of Three Energy Efficient Building Technologies
}

Conference Paper NREL/CP-550-48125

August 2010

\section{Preprint}

James P. Miller, Alexander Zhivov, and Dale Heron U.S. Army

Michael Deru and Kyle Benne National Renewable Energy Laboratory

Presented at ASME $20104^{\text {th }}$ International Conference on Energy Sustainability (ES2010)

Phoenix, Arizona

May 17-22, 2010 


\section{NOTICE}

The submitted manuscript has been offered by an employee of the Alliance for Sustainable Energy, LLC (ASE), a contractor of the US Government under Contract No. DE-AC36-08-GO28308. Accordingly, the US Government and ASE retain a nonexclusive royalty-free license to publish or reproduce the published form of this contribution, or allow others to do so, for US Government purposes.

This report was prepared as an account of work sponsored by an agency of the United States government. Neither the United States government nor any agency thereof, nor any of their employees, makes any warranty, express or implied, or assumes any legal liability or responsibility for the accuracy, completeness, or usefulness of any information, apparatus, product, or process disclosed, or represents that its use would not infringe privately owned rights. Reference herein to any specific commercial product, process, or service by trade name, trademark, manufacturer, or otherwise does not necessarily constitute or imply its endorsement, recommendation, or favoring by the United States government or any agency thereof. The views and opinions of authors expressed herein do not necessarily state or reflect those of the United States government or any agency thereof.

Available electronically at http://www.osti.gov/bridge

Available for a processing fee to U.S. Department of Energy and its contractors, in paper, from:

U.S. Department of Energy

Office of Scientific and Technical Information

P.O. Box 62

Oak Ridge, TN 37831-0062

phone: 865.576.8401

fax: 865.576 .5728

email: mailto:reports@adonis.osti.gov

Available for sale to the public, in paper, from:

U.S. Department of Commerce

National Technical Information Service

5285 Port Royal Road

Springfield, VA 22161

phone: 800.553.6847

fax: 703.605.6900

email: orders@ntis.fedworld.gov

online ordering: http://www.ntis.gov/ordering.htm 


\section{A PRACTICAL INTEGRATION APPROACH AND WHOLE BUILDING ENERGY SIMULATION OF THREE ENERGY EFFICIENT BUILDING TECHNOLOGIES}

\author{
James P. Miller \\ U.S. Army ERDC-CERL \\ Champaign, Illinois, USA \\ james.p.miller@usace.army.mil
}

\author{
Michael Deru \\ National Renewable Energy Laboratory \\ Golden, Colorado, USA \\ michael.deru@nrel.gov
}

\author{
Kyle Benne \\ National Renewable Energy \\ Laboratory \\ Golden, Colorado, USA \\ kyle.benne@nrel.gov
}

\author{
Alexander Zhivov \\ U.S. Army ERDC-CERL \\ Champaign, Illinois, USA \\ alexander.m.zhivov@usace.army.mil
}

\author{
Dale Herron \\ U.S. Army ERDC-CERL \\ Champaign, Illinois, USA \\ dale.I.herron@usace.army.mil
}

\begin{abstract}
Rising energy costs and the desire to reduce energy consumption dictates a need for significantly improved building energy performance. Three technologies that have potential to save energy and improve sustainability of buildings are dedicated outdoor air systems (DOAS), radiant heating and cooling systems and tighter building envelopes.

Although individually applying innovative technologies may incrementally improve building energy performance, more significant payoffs are realized when compatible technologies are integrated into an optimized system. Fortunately, DOAS, radiant heating and cooling systems and improved building envelopes are highly compatible.

To investigate the energy savings potential of these three technologies, whole building energy simulations were performed for a barracks facility and an administration facility in 15 U.S. climate zones and 16 international locations. The baseline facilities were assumed to be existing buildings with VAV HVAC systems (admin facilities) and packaged HVAC systems (barracks facilities). The energy simulations were adjusted for each location for optimal energy and humidity control performance. The results show that the upgraded facilities realized total building energy savings between $20 \%$ and $40 \%$ and improved humidity control when compared to baseline building performance.
\end{abstract}

\section{INTRODUCTION}

Building owners and designers are increasingly interested in building energy systems that cost effectively reduce energy consumption and energy costs while maintaining comfort and acceptable indoor air quality. Three technologies that have potential for significant energy savings are dedicated outdoor air systems (DOAS), radiant heating/cooling systems, and tighter building envelopes. While each of these technologies, applied individually, can realize energy savings, it is important to think in terms of a systems approach rather than just applying these technologies individually. For example, radiant cooling systems have the potential to save a great deal of energy when compared to all-air heating/cooling systems, primarily due to a major reduction in fan energy. Unfortunately, major moisture and condensation problems can occur if the space dew point temperature (DPT) is not maintained below the surface temperature of the radiant cooling system components. Tighter building envelopes reduce the heating, cooling and dehumidification energy required to overcome the effects of uncontrolled infiltration of outdoor air. They also reduce the amount of makeup air required to maintain positive pressurization of the building.

\section{BASELINE BUILDING DESCRIPTIONS}

To better understand the energy impacts of these technologies, we modeled two building types (an administrative facility and a barracks facility) in fifteen

This material is declared a work of the U.S. Government and is not subject to copyright protection in the United States. Approved for public release; distribution is unlimited. 
U.S. climate zones and sixteen international locations using EnergyPlus. Administration and barracks facilities are the two most common building types in the U.S. Army. Admin facilities are similar in many respects to private sector office buildings and barracks facilities bear similarities to many apartment buildings and hotel buildings with interior corridors. For this study, we developed each baseline facility model in compliance with the requirements of ASHRAE Standard 90.1-1989 (ASHRAE 1989) since the Army has a large inventory of existing admin and barracks facilities which were designed and constructed in accordance with this standard and are current candidates for major renovation and upgrade. For each facility type, we developed "improved" facility models which included DOAS and radiant heating/cooling systems and a "further improved" facility model which included DOAS, radiant heating/cooling and a tighter building envelope. Renderings of the baseline facilities are shown in Figs. 1 and 2 below. Technical specifications are provided in Tables 1 and 2.

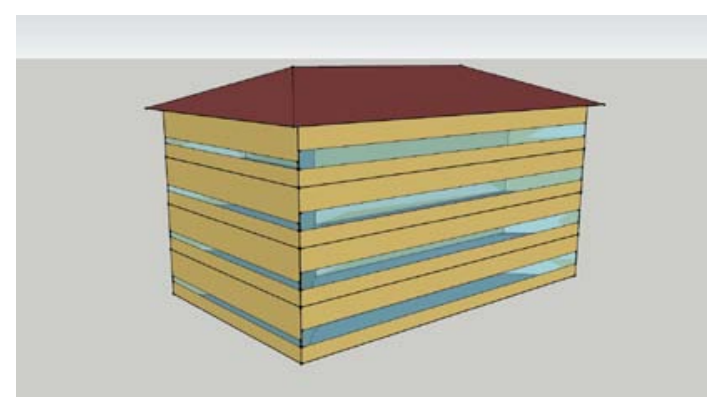

Figure 1. Rendering of modeled administration facility credit: Kyle Benne/NREL

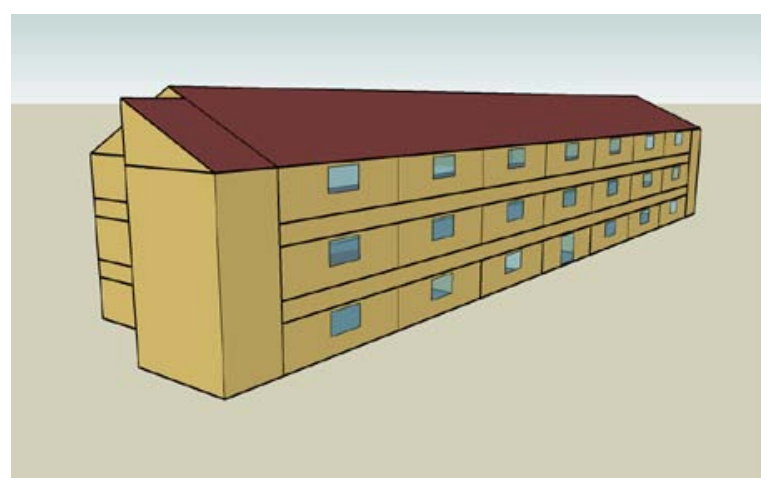

Figure 2. Rendering of modeled barracks facility credit: Michael Deru/NREL
Table 1. Baseline administrative facility

\begin{tabular}{|c|c|}
\hline $\begin{array}{c}\text { Building } \\
\text { Component }\end{array}$ & Component Description \\
\hline Area (total) & $23,250 \mathrm{ft}^{2}\left(2,160 \mathrm{~m}^{2}\right)$ \\
\hline Floors & 4 \\
\hline $\begin{array}{l}\text { Foot print } \\
\text { shape }\end{array}$ & Rectangle \\
\hline $\begin{array}{l}\text { Fenestration } \\
\text { type }\end{array}$ & Standard 90.1-1989 \\
\hline $\begin{array}{l}\text { Wall } \\
\text { construction }\end{array}$ & Steel frame with brick exterior \\
\hline Wall insulation & Standard 90.1-1989, mass wall \\
\hline $\begin{array}{l}\text { Roof } \\
\text { construction }\end{array}$ & $\begin{array}{l}\text { Sloped metal roof with insulation at roof } \\
\text { level }\end{array}$ \\
\hline Roof insulation & Standard 90.1-1989, with attic \\
\hline Infiltration & $\begin{array}{l}1 \mathrm{cfm} / \mathrm{ft}^{2}\left(5.08 \mathrm{~L} / \mathrm{s}-\mathrm{m}^{2}\right) \text { of shell area at } 0.3 \\
\text { iwg }(75 \mathrm{~Pa})\end{array}$ \\
\hline $\begin{array}{l}\text { Window-to-wall } \\
\text { ratio }\end{array}$ & $\begin{array}{l}\text { Total - } 23.44 \% \text {; North }-30.00 \% \text {; East - } \\
12.51 \% \text {; South - 30.00\%; West - } 12.51 \%\end{array}$ \\
\hline $\begin{array}{l}\text { Temperature } \\
\text { set points }\end{array}$ & $\begin{array}{l}75^{\circ} \mathrm{F}\left(23.9^{\circ} \mathrm{C}\right) \text { cooling and } 70{ }^{\circ} \mathrm{F}\left(21.1^{\circ} \mathrm{C}\right) \\
\text { heating with night setback to } 86{ }^{\circ} \mathrm{F}\left(30^{\circ} \mathrm{C}\right) \\
\text { cooling and } 60^{\circ} \mathrm{F}\left(15.6{ }^{\circ} \mathrm{C}\right) \text { heating }\end{array}$ \\
\hline Ventilation & $20 \mathrm{cfm}(9.44 \mathrm{~L} / \mathrm{s})$ per person \\
\hline HVAC & $\begin{array}{l}\text { VAV system with central chiller ( } 4.5 \mathrm{COP}) \\
\text { and natural gas boiler }(0.8 \mathrm{Et})\end{array}$ \\
\hline $\mathrm{DHW}$ & Natural gas boiler (0.8 Et ) \\
\hline
\end{tabular}

Table 2. Baseline barracks facility

\begin{tabular}{|c|c|}
\hline $\begin{array}{l}\text { Building } \\
\text { Component }\end{array}$ & Component Description \\
\hline Area (total) & $28,965 \mathrm{ft}^{2}\left(2,691 \mathrm{~m}^{2}\right)$ \\
\hline Floors & 3 \\
\hline Foot print shape & Rectangle \\
\hline $\begin{array}{l}\text { Fenestration } \\
\text { type }\end{array}$ & Standard 90.1-1989 \\
\hline $\begin{array}{l}\text { Wall } \\
\text { construction }\end{array}$ & Wood frame with brick exterior \\
\hline Wall insulation & Standard 90.1-1989, mass wall \\
\hline $\begin{array}{l}\text { Roof } \\
\text { construction }\end{array}$ & $\begin{array}{l}\text { Sloped metal roof with Insulation at roof } \\
\text { Level }\end{array}$ \\
\hline Roof insulation & Standard 90.1-1989, with attic \\
\hline Infiltration & $\begin{array}{l}1 \mathrm{cfm} / \mathrm{ft}^{2}\left(5.08 \mathrm{~L} / \mathrm{s}-\mathrm{m}^{2}\right) \text { of shell area at } 0.3 \\
\operatorname{iwg}(75 \mathrm{~Pa})\end{array}$ \\
\hline $\begin{array}{l}\text { Window-to-wall } \\
\text { ratio }\end{array}$ & $\begin{array}{l}\text { Total - 6.88\%; North }-8.91 \% \text {; East - } \\
0.00 \% \text {; South - } 9.38 \% \text {; West }-0.00 \%\end{array}$ \\
\hline $\begin{array}{l}\text { Temperature set } \\
\text { points }\end{array}$ & $\begin{array}{l}75^{\circ} \mathrm{F}\left(23.9^{\circ} \mathrm{C}\right) \text { cooling and } 70^{\circ} \mathrm{F}(21.1 \\
\left.{ }^{\circ} \mathrm{C}\right) \text { heating }\end{array}$ \\
\hline Ventilation & $75 \mathrm{cfm}(35.4 \mathrm{~L} / \mathrm{s})$ continuous per unit \\
\hline HVAC & $\begin{array}{l}\text { PSZ with DX-AC (2.6 COP) and gas } \\
\text { furnace }(0.8 \mathrm{Et})\end{array}$ \\
\hline $\mathrm{DHW}$ & Natural gas boiler (0.8 Et ) \\
\hline
\end{tabular}

The models assumed that the administrative facility was occupied during typical business hours, five days per week. During unoccupied hours, the system enters night cycle mode where outside ventilation air is shut off and zone temperature controls are set back (set up). The barracks facility models 
assumed that the heating, cooling and ventilating systems were in occupied mode 24 hours per day, 365 days per year.

The baseline administrative facility used chilled water from an air-cooled chiller and hot water reheat at the VAV terminal units supplied by a central gas boiler.

The floor plan of the barracks facility is similar to an apartment building with each unit designed for occupancy by two soldiers. Temperature control in each baseline barracks unit is handled by a single zone constant speed air system cooled by DX and heated by a natural gas furnace.

\section{IMPROVED BUILDING DESCRIPTIONS}

The "improved" admin facility uses radiant heating/cooling panels served by chilled water from an air-cooled chiller and hot water from a gas boiler. A constant volume DOAS provides conditioned ventilation air only during occupied hours. The DOAS supply air temperature is governed by an outside air temperature reset schedule. The DOAS provides minimal sensible heating/cooling through water coils supplied by a gas boiler and a chilled water coil supplied by a second air-cooled chiller. The water loops feeding the DOAS are separate from the radiant system. The primary space sensible load is designed to be met by the radiant heating/cooling system.

The HVAC system for the "improved" barracks facility is essentially the same as for the "improved" administrative facility. The major difference is that the "improved" barracks facility is assumed to be constantly occupied, thus the DOAS system runs continuously. The DOAS system models for both the administrative facility and barracks facility include total energy recovery (TER) to extract energy from the buildings' exhaust air streams.

The "further improved" models for both the administrative facility and the barracks facility incorporate tighter building envelopes in addition to the DOAS system and radiant heating/cooling system in the "improved" models. Tighter building envelopes reduce infiltration from $1.0 \mathrm{cfm} / \mathrm{ft}^{2}\left(5.08 \mathrm{~L} / \mathrm{s}-\mathrm{m}^{2}\right)$ at a reference pressure difference of $75 \mathrm{~Pa}$ between the building interior and the outdoor ambient conditions in the baseline facilities to $0.25 \mathrm{cfm} / \mathrm{ft}^{2}\left(1.27 \mathrm{~L} / \mathrm{s}^{2} \mathrm{~m}^{2}\right)$ at a $75 \mathrm{~Pa}$ pressure difference in the "further improved" models.

\section{SELECTED SIMULATION LOCATIONS AND CORRESPONDING ENERGY COSTS}

Fifteen locations were selected to represent fifteen climate zones in the United States. The U.S. locations were selected as representative cities for the climate zones by the Pacific Northwest National Laboratory
(Briggs et al. 2003). In addition, 16 locations were selected outside of the U.S. in Canada and Europe. The 15 U.S. and 16 non U.S. locations are shown in Tables 3 and 4 . Both tables include the ASHRAE Standard 90.1-1989 table numbers for the locations that were used to select the envelope thermal criteria. The 90.1-1989 tables for the non U.S. locations were selected based on the heating degree days (HDD) and cooling degree days (CDD).

Table 3. U.S. Climate Zones and Cities used for Simulations

\begin{tabular}{|c|c|c|c|c|}
\hline $\begin{array}{c}\text { Climate } \\
\text { Zone }\end{array}$ & $\begin{array}{c}\text { ASHRAE } \\
90.1- \\
1989 \\
\text { Table }\end{array}$ & City & $\begin{array}{c}\text { HDD, } \\
6^{\circ}{ }^{\circ} \mathrm{F} \\
(18.3 \\
\left.{ }^{\circ} \mathrm{C}\right) \\
\end{array}$ & $\begin{array}{c}\text { CDD, } \\
50^{\circ} \mathrm{F} \\
\left(10^{\circ} \mathrm{C}\right)\end{array}$ \\
\hline $1 \mathrm{~A}$ & 5 & Miami, FL & $\begin{array}{c}200 \\
(111)\end{array}$ & $\begin{array}{c}9474 \\
(5263) \\
\end{array}$ \\
\hline $2 \mathrm{~A}$ & 10 & Houston, TX & $\begin{array}{l}1599 \\
(888) \\
\end{array}$ & $\begin{array}{r}6876 \\
(3820) \\
\end{array}$ \\
\hline $2 \mathrm{~B}$ & 12 & Phoenix, AZ & $\begin{array}{l}1350 \\
(750)\end{array}$ & $\begin{array}{r}8425 \\
(4681) \\
\end{array}$ \\
\hline $3 \mathrm{~A}$ & 15 & Memphis, TN & $\begin{array}{c}3082 \\
(1712)\end{array}$ & $\begin{array}{c}5467 \\
(3037) \\
\end{array}$ \\
\hline $3 \mathrm{~B}$ & 18 & El Paso, TX & $\begin{array}{c}2708 \\
(1504) \\
\end{array}$ & $\begin{array}{c}5488 \\
(3049) \\
\end{array}$ \\
\hline $3 \mathrm{C}$ & 19 & $\begin{array}{l}\text { San Francisco, } \\
\text { CA }\end{array}$ & $\begin{array}{c}3016 \\
(1676)\end{array}$ & $\begin{array}{c}2883 \\
(1602) \\
\end{array}$ \\
\hline $4 \mathrm{~A}$ & 23 & Baltimore, MD & $\begin{array}{c}4707 \\
(2615)\end{array}$ & $\begin{array}{r}3709 \\
(2061) \\
\end{array}$ \\
\hline $4 \mathrm{~B}$ & 24 & $\begin{array}{l}\text { Albuquerque, } \\
\text { NM }\end{array}$ & $\begin{array}{c}4425 \\
(2458) \\
\end{array}$ & $\begin{array}{r}3908 \\
(2171) \\
\end{array}$ \\
\hline $4 \mathrm{C}$ & 25 & Seattle, WA & $\begin{array}{c}4908 \\
(2727) \\
\end{array}$ & $\begin{array}{c}1823 \\
(1013) \\
\end{array}$ \\
\hline $5 \mathrm{~A}$ & 26 & Chicago, IL & $\begin{array}{c}6536 \\
(3631)\end{array}$ & $\begin{array}{c}2941 \\
(1634)\end{array}$ \\
\hline $5 \mathrm{~B}$ & 28 & Boise, ID & $\begin{array}{c}5882 \\
(3231)\end{array}$ & $\begin{array}{c}2716 \\
(1509)\end{array}$ \\
\hline $6 \mathrm{~A}$ & 32 & Burlington, VT & $\begin{array}{c}7771 \\
(4317)\end{array}$ & $\begin{array}{c}2228 \\
(1238) \\
\end{array}$ \\
\hline $6 \mathrm{~B}$ & 33 & Helena, MT & $\begin{array}{r}7699 \\
(4277) \\
\end{array}$ & $\begin{array}{c}1841 \\
(1023) \\
\end{array}$ \\
\hline $7 \mathrm{~A}$ & 36 & Duluth, MN & $\begin{array}{c}9818 \\
(5454) \\
\end{array}$ & $\begin{array}{l}1536 \\
(853) \\
\end{array}$ \\
\hline $8 \mathrm{~A}$ & 38 & Fairbanks, AK & $\begin{array}{r}13940 \\
(7744)\end{array}$ & $\begin{array}{l}1040 \\
(578)\end{array}$ \\
\hline
\end{tabular}

Flat utility tariffs were assumed for each location (i.e. no energy demand charges are included). The U.S. energy costs are based on flat rates at the average for commercial rates in each state and may not reflect the utility rates at a specific location. A fixed price was assumed for all non U.S. cities as shown in Table 5. 
Table 4. Non U.S. Climate Zones and Cities used for Simulations

\begin{tabular}{|c|c|c|c|c|}
\hline $\begin{array}{c}\text { Climate } \\
\text { Zone }\end{array}$ & $\begin{array}{c}\text { ASHRAE } \\
90.1 \text { - } \\
1989 \\
\text { Table }\end{array}$ & City & $\begin{array}{c}\text { HDD, } \\
\mathbf{6 5}^{\circ} \mathrm{F} \\
(18.3 \\
\left.{ }^{\circ} \mathrm{C}\right)\end{array}$ & $\begin{array}{c}\text { CDD, } \\
50^{\circ} \mathrm{F} \\
\left(10^{\circ} \mathrm{C}\right)\end{array}$ \\
\hline 7 & 36 & Edmonton, CAN & $\begin{array}{l}10049 \\
(5583)\end{array}$ & $\begin{array}{l}1042 \\
(579)\end{array}$ \\
\hline 6 & 33 & Ottawa, CAN & $\begin{array}{c}8395 \\
(4664)\end{array}$ & $\begin{array}{c}2014 \\
(1119)\end{array}$ \\
\hline 5 & 19 & Vancouver, CAN & $\begin{array}{c}5436 \\
(3020)\end{array}$ & $\begin{array}{l}1451 \\
(806) \\
\end{array}$ \\
\hline 5 & 28 & Stuttgart, DEU & $\begin{array}{c}6008 \\
(3338)\end{array}$ & $\begin{array}{c}2340 \\
(1300)\end{array}$ \\
\hline 5 & 28 & $\begin{array}{l}\text { Copenhagen, } \\
\text { DNK }\end{array}$ & $\begin{array}{c}6413 \\
(3563)\end{array}$ & $\begin{array}{l}1283 \\
(713) \\
\end{array}$ \\
\hline 7 & 33 & Helsinki, FIN & $\begin{array}{c}8482 \\
(4712)\end{array}$ & $\begin{array}{l}1039 \\
(577)\end{array}$ \\
\hline 7 & 33 & Tampere, FIN & $\begin{array}{c}9036 \\
(5020) \\
\end{array}$ & $\begin{array}{c}950 \\
(528) \\
\end{array}$ \\
\hline 4 & 20 & Lyon, FRA & $\begin{array}{c}4570 \\
(2539) \\
\end{array}$ & $\begin{array}{c}2669 \\
(1483) \\
\end{array}$ \\
\hline 4 & 3 & Marseille, FRA & $\begin{array}{c}3123 \\
(1735)\end{array}$ & $\begin{array}{c}3789 \\
(2105)\end{array}$ \\
\hline 4 & 4 & Nantes, FRA & $\begin{array}{c}4057 \\
(2254)\end{array}$ & $\begin{array}{c}2360 \\
(1311)\end{array}$ \\
\hline 4 & 19 & Paris, FRA & $\begin{array}{c}4759 \\
(2644)\end{array}$ & $\begin{array}{c}2176 \\
(1209)\end{array}$ \\
\hline 4 & 19 & London, GBR & $\begin{array}{c}5159 \\
(2866) \\
\end{array}$ & $\begin{array}{l}1555 \\
(864) \\
\end{array}$ \\
\hline 4 & 25 & Milan, ITA & $\begin{array}{c}4750 \\
(2639)\end{array}$ & $\begin{array}{c}2947 \\
(1637)\end{array}$ \\
\hline 4 & 9 & Naples, ITA & $\begin{array}{c}2455 \\
(1364) \\
\end{array}$ & $\begin{array}{c}4473 \\
(2485) \\
\end{array}$ \\
\hline 2 & 9 & Palermo, ITA & $\begin{array}{r}1303 \\
(724) \\
\end{array}$ & $\begin{array}{c}5805 \\
(3225) \\
\end{array}$ \\
\hline 4 & 24 & Rome, ITA & $\begin{array}{r}2599 \\
(1444) \\
\end{array}$ & $\begin{array}{r}4199 \\
(2333) \\
\end{array}$ \\
\hline
\end{tabular}

Table 5. Energy rates used in simulations

\begin{tabular}{|l|c|c|}
\hline \multicolumn{1}{|c|}{ City } & $\begin{array}{c}\text { Electricity } \\
\text { Cost } \\
\mathbf{\$} \mathbf{k W h}\end{array}$ & $\begin{array}{c}\text { Natural Gas Cost } \\
\text { (\$/Million Btu) }\end{array}$ \\
\hline Miami, FL & $\$ 0.0761$ & $\$ 11.44$ \\
\hline Houston, TX & $\$ 0.0787$ & $\$ 8.42$ \\
\hline Phoenix, AZ & $\$ 0.0724$ & $\$ 8.71$ \\
\hline Memphis, TN & $\$ 0.0706$ & $\$ 9.63$ \\
\hline El Paso, TX & $\$ 0.0787$ & $\$ 8.42$ \\
\hline San Francisco, CA & $\$ 0.1160$ & $\$ 8.50$ \\
\hline Baltimore, MD & $\$ 0.0753$ & $\$ 9.23$ \\
\hline Albuquerque, NM & $\$ 0.0738$ & $\$ 8.19$ \\
\hline Seattle, WA & $\$ 0.0620$ & $\$ 9.40$ \\
\hline Chicago, IL & $\$ 0.0752$ & $\$ 9.82$ \\
\hline Boise, ID & $\$ 0.0537$ & $\$ 8.54$ \\
\hline Burlington, VT & $\$ 0.1142$ & $\$ 8.76$ \\
\hline Helena, MT & $\$ 0.0740$ & $\$ 9.64$ \\
\hline Duluth, MN & $\$ 0.0630$ & $\$ 8.36$ \\
\hline Fairbanks, AK & $\$ 0.1100$ & $\$ 4.08$ \\
\hline All non U.S. cities & $\$ 0.0929$ & $\$ 10.67$ \\
\hline
\end{tabular}

\section{U.S. MODELING RESULTS - ADMIN FACILITY}

Figures 3 through 5 show the electrical, gas and total energy consumption results for the baseline and "improved" administration facility. In all cases, except San Francisco, the addition of DOAS and radiant heating/cooling resulted in decreased electrical consumption. The reduced electrical consumption was most evident in hot or hot/humid locations (i.e., Miami, Houston, Phoenix and El Paso).

Figure 4 shows significant gas energy savings in the cooler and cold locations. This would appear to be a result of the greater efficiency of radiant heating systems than all-air systems.

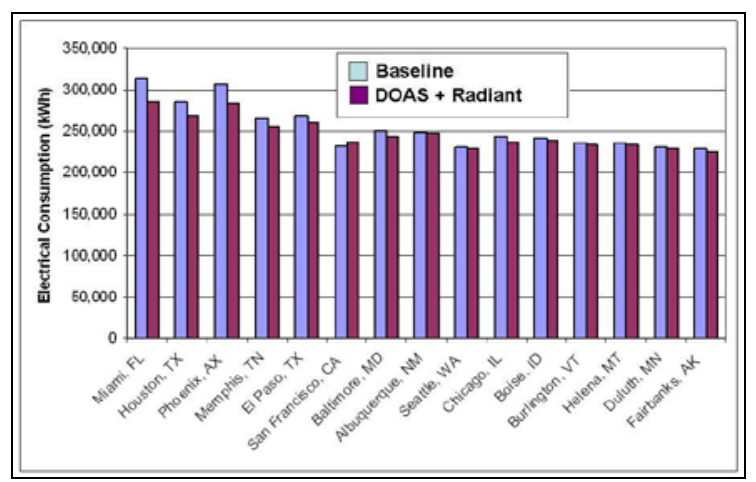

Figure 3. Admin - electrical consumption

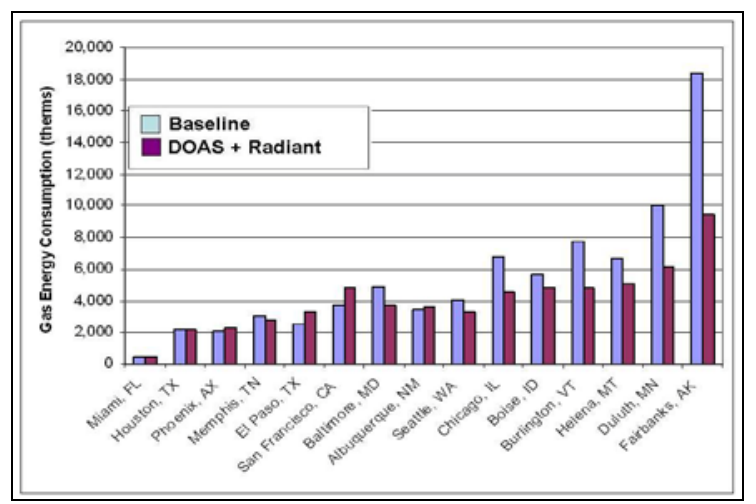

Figure 4. Admin - gas energy consumption

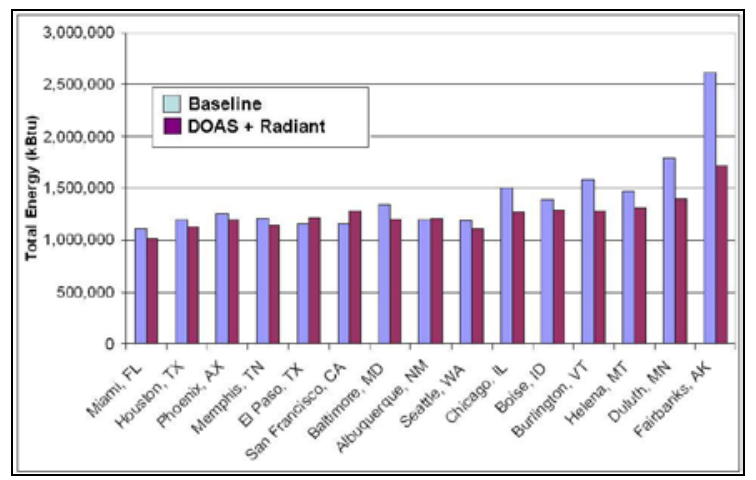

Figure 5. Admin - total energy consumption 
Figure 5 indicates that the DOAS + Radiant systems save energy in most climate locations. In El Paso, San Francisco, and Albuquerque the "improved" system appears to consume more energy than the baseline system. This is further illustrated in Fig. 6 where these locations have negative energy savings. Other locations in Fig. 6 show substantial energy savings, especially in the cooler/cold locations.

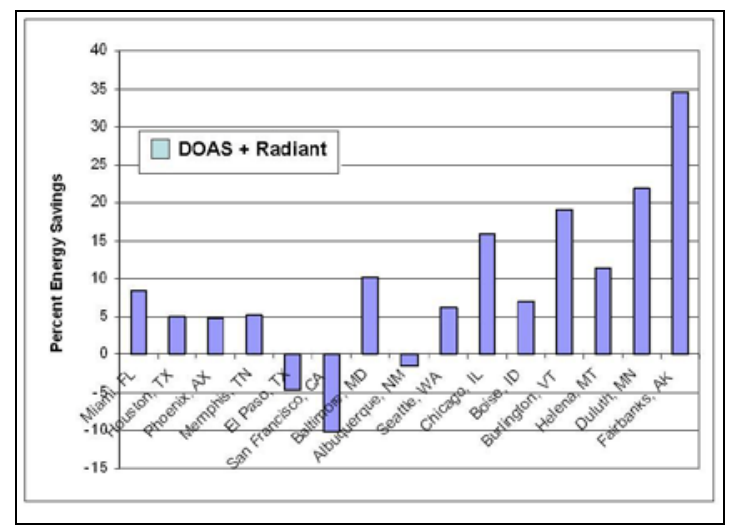

Figure 6. Admin - percent energy savings

Figure 7 illustrates the difference in air flow required by the baseline admin facilities as compared to the "improved" facilities using DOAS + radiant heating/cooling systems. The baseline facilities deliver conditioned air to not only ventilate the building but also to control space temperature. By handling space temperature control through the radiant systems, considerable reduction in air flow rates is possible.

Figures 8 through 12 show modeled results for the barracks facility, including both the "improved" case (i.e., DOAS and radiant heating/cooling) and the "further improved" case (i.e., DOAS plus radiant heating/cooling plus tighter building envelope). In Fig. 8 , one can see that both improved systems showed significant electrical energy reductions in most U.S. locations. This is especially interesting when comparing the barracks facility results in Fig. 8 with the administration facility results in Fig. 3.

Very significant gas energy savings are shown in Fig. 9, especially in cooler/cold locations. There is also a significant reduction in gas energy consumption in the buildings with improved envelopes as compared to the buildings with DOAS and radiant only. This would seem to be due to decreased heating loads resulting from diminished infiltration of cold air as a result of improved building envelopes.

Figure 10 shows the total energy consumption performance of the baseline, "improved" and "further improved" barracks facilities.

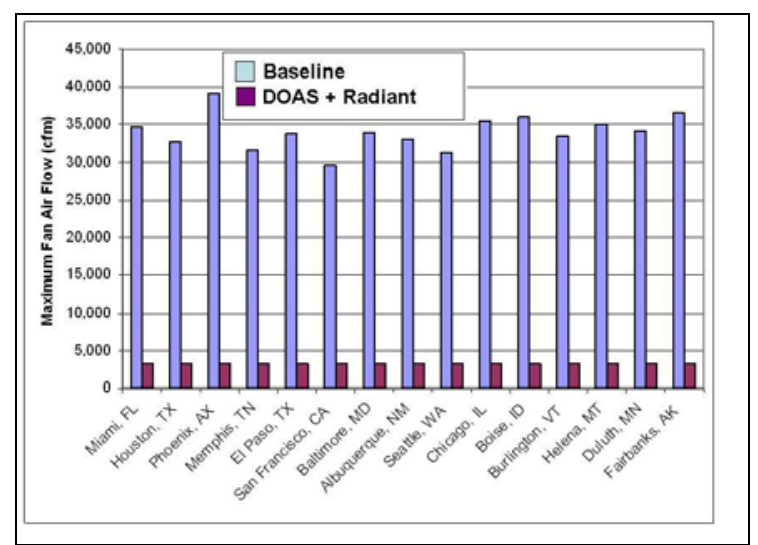

Figure 7. Admin - maximum air flow (cfm)

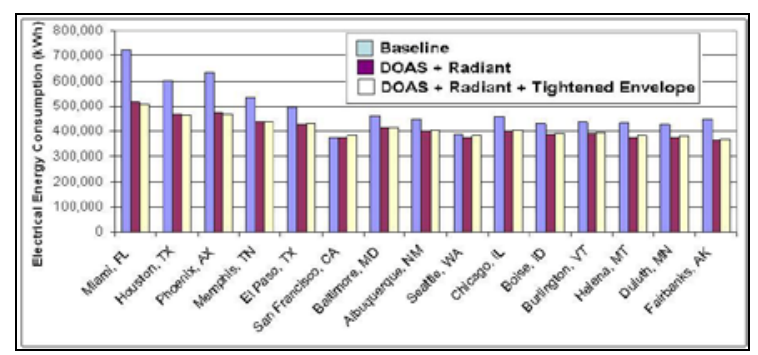

Figure 8. Barracks - electrical energy consumption

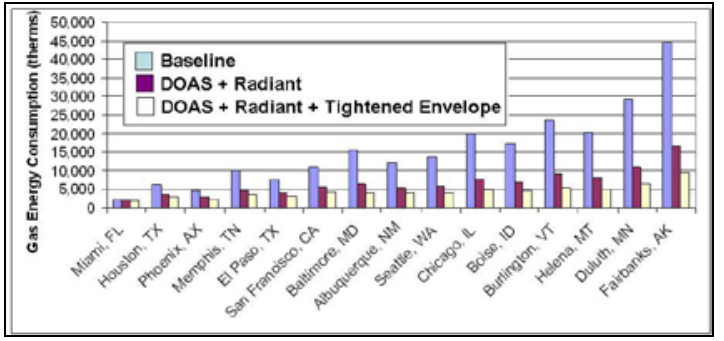

Figure 9. Barracks - gas energy consumption

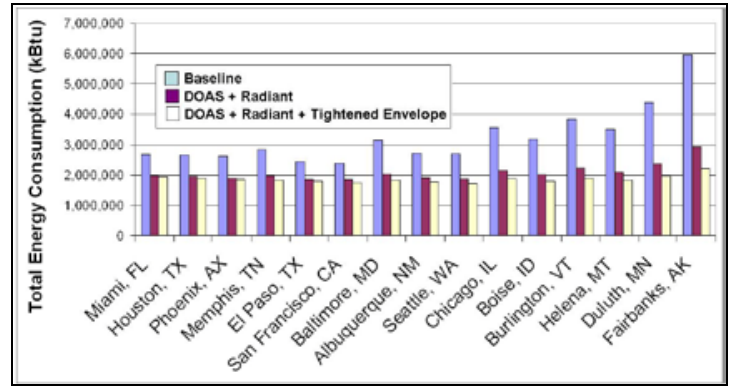

Figure 10. Barracks - total energy consumption

In Fig. 11 one can see that the "improved" and "further improved" barracks facilities save considerable energy over the baseline facilities. 


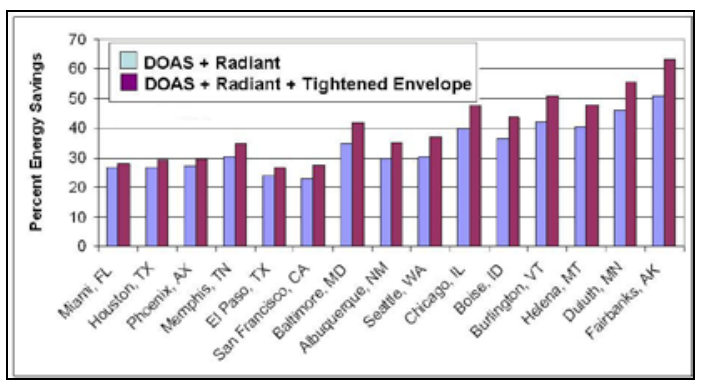

Figure 11. Barracks - percent energy savings

Figure 12 illustrates the difference in air flow required by the baseline barracks facilities as compared to the "improved" and "further improved" facilities. As with the administration facilities, the baseline barracks facilities deliver conditioned air to not only ventilate the building but also to control space temperature. By handling space temperature control through the radiant systems, considerable reduction in air flow rates (and related fan energy) is achieved.

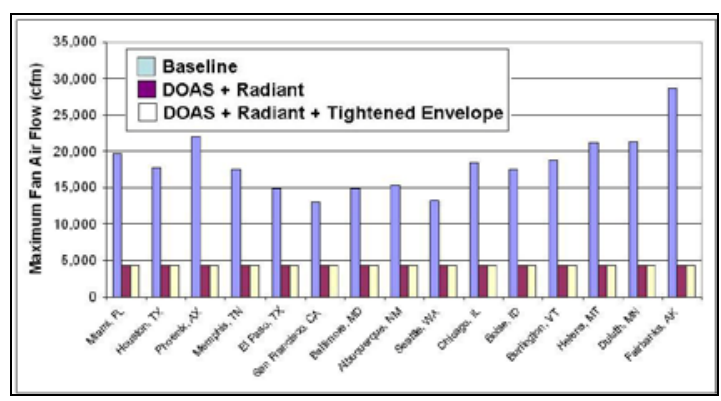

Figure 12. Barracks - maximum fan air flow (cfm)

\section{INTERNATIONAL MODELING RESULTS}

Similar simulations were performed for the administration building in sixteen international locations. In Fig. 13, one can see that the "improved" administration facility had significantly reduced electrical energy consumption in all locations when compared to the baseline facility. However, the electrical savings appeared to be achieved at the expense of an increase of gas usage in most locations as shown in Fig. 14. Nevertheless, when electrical and gas energy consumption was calculated, the total energy of the "improved" administration facilities was less than for the baseline facility at all locations as shown in Fig. 15. Figure 16 shows that the "improved" systems realized significant energy savings, ranging from a low of $8 \%$ (Paris) to $48 \%$ (Stuttgart).

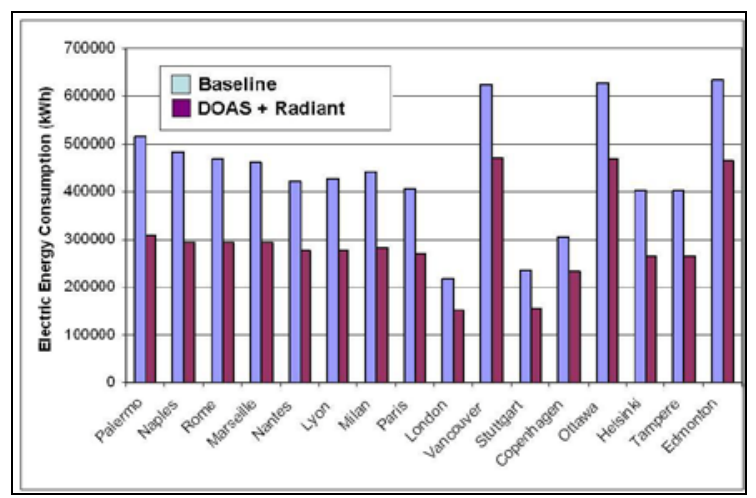

Figure 13. Admin - electrical energy consumption

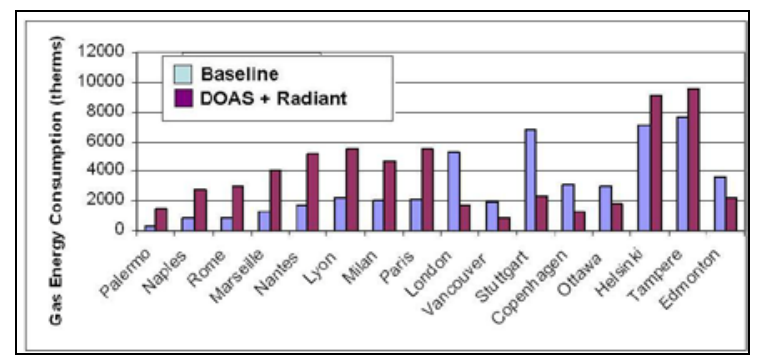

Figure 14. Admin - gas energy consumption

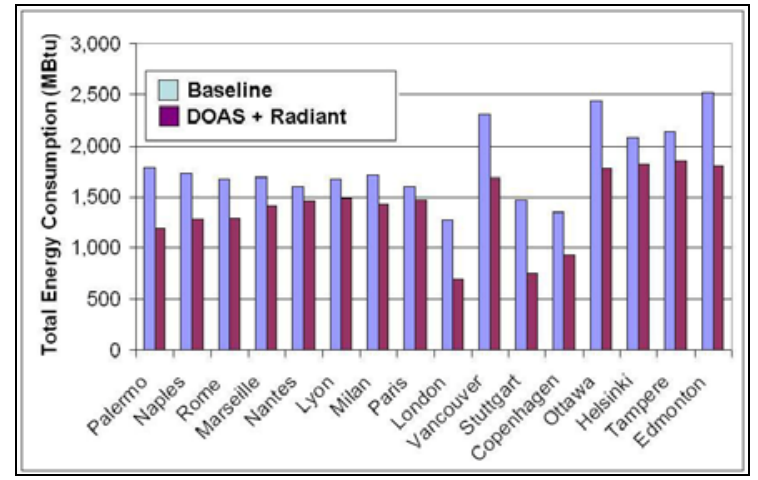

Figure 15. Admin - total energy consumption

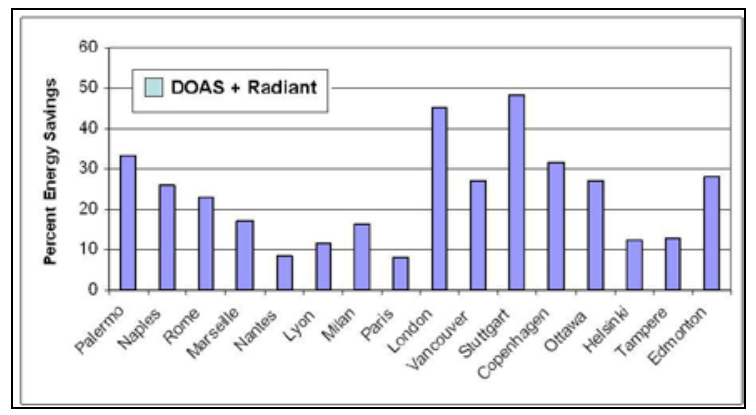

Figure 16. Admin - percent energy savings

Figures 17 and 18 show the annual energy cost savings for U.S. and non U.S. locations. 


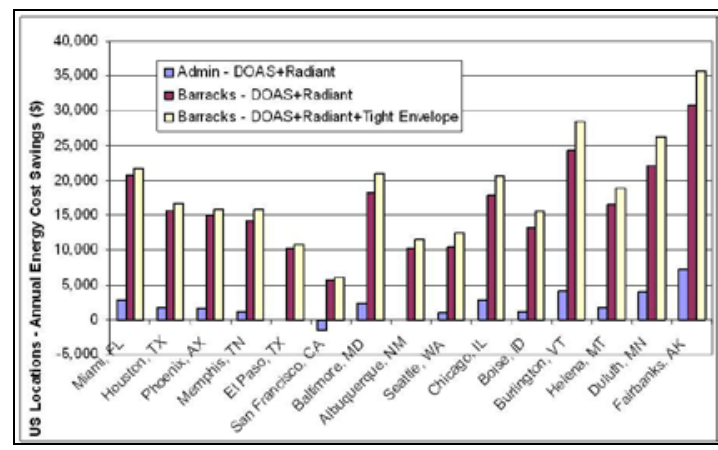

Figure 17. Annual energy cost savings - US locations

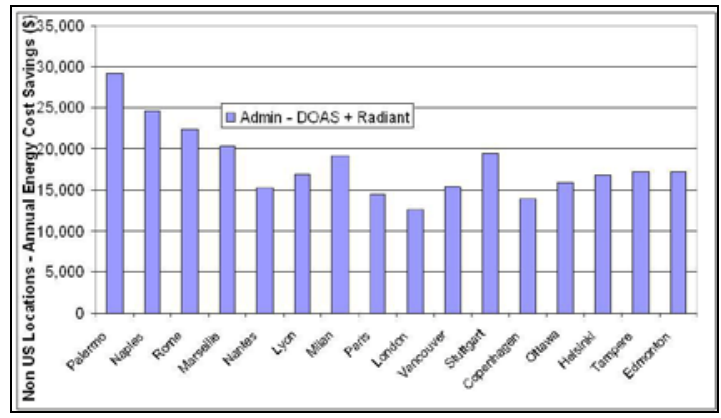

Figure 18. Annual energy cost savings - Non US locations

\section{ECONOMIC CONSIDERATIONS}

In most instances, it would be hard to justify the costs of performing a major facility renovation if one's primary motivation for the project was energy conservation. However, in the case of a major facility renovation project, enhanced efficiency features can make good economic sense.

The U.S. Army recently conducted a study at Fort Irwin, $\mathrm{CA}$, to identify possibilities of transitioning the Army towards Net Zero Energy installations. A group of five barracks facilities (each about 25 years old and similar in size and configuration to the barracks facility modeled in this study) were included in the Fort Irwin study. These buildings were studied to determine optional approaches to upgrading the facilities to significantly improve their energy performance.

Under the Army's Barracks Upgrade Program (BUP), barracks facilities typically become eligible for major upgrades at about 25 years of age. A typical upgrade project would normally include complete interior renovation and improving the building envelope with tighter fitting, better insulated doors and more energy efficient windows. Lighting, mechanical systems and appliances are also replaced. Typically, a newly upgraded barracks facility will realize about $8 \%$ electrical energy savings and $7 \%$ heating energy savings. Although not insignificant, this is not very satisfactory when one considers the amount of money invested in the barracks upgrade project, particularly when one's ultimate goal is to move towards a Net Zero Energy installation.

In a typical barracks upgrade project, existing twopipe fan coil units and makeup air units are replaced in kind. In the Fort Irwin study, four optional approaches to upgrading the mechanical systems were explored. These optional systems include:

- Option 1 - VAV DOAS with Direct Evaporative Cooling

- Option 2 - VAV DOAS system with Radiant Heating/Cooling (including direct and indirect evaporative cooling)

- Option 3 - VAV DOAS system with Fan Coils (including direct and indirect evaporative cooling)

- Option 4 - VAV DOAS with Direct and Indirect Evaporative Cooling

Cost estimates for the baseline mechanical system and each of the optional mechanical systems were prepared. Of the four optional approaches investigated in the Fort Irwin study, Option 2 is most similar to the "improved" system discussed in this study. As a result, the estimated costs of a typical mechanical system upgrade and a DOAS system with radiant heating/cooling (including direct and indirect evaporative cooling) are compared in Table 6 below. In Table 7, other work elements common to a typical barracks upgrade project and an upgrade project performed in accordance with Option 2 are compared.

Table 6. Comparison of estimated retrofit costs

\begin{tabular}{|c|c|c|}
\hline $\begin{array}{l}\text { Typical } \\
\text { Upgrade } \\
\text { Project }\end{array}$ & $\begin{array}{l}\text { Option } 2 \\
\text { Approach }\end{array}$ & Mechanical System Elements \\
\hline & $\$ 10,000$ & $\begin{array}{l}\text { DOAS-VAV AHU with Direct Evap } \\
\text { cooling }\end{array}$ \\
\hline & $\$ 20,000$ & Indirect evaporative coolers \\
\hline & $\$ 35,000$ & $\begin{array}{l}\text { Pad/Equipment enclosure for external } \\
\text { equipment }\end{array}$ \\
\hline & $\$ 10,000$ & $\begin{array}{l}\text { Duct riser from equipment enclosure } \\
\text { into building }\end{array}$ \\
\hline & $\$ 15,000$ & Electrical power to equipment pad \\
\hline$\$ 35,000$ & $\$ 35,000$ & $\begin{array}{l}\text { CHW Piping to AHU dynamic } 2 \text { pipe } \\
\text { switchover }\end{array}$ \\
\hline$\$ 18,000$ & $\$ 18,000$ & Ductwork for toilet exhaust system \\
\hline$\$ 5,000$ & $\$ 5,000$ & Electrical for exhaust fan system \\
\hline \multirow[t]{2}{*}{$\$ 30,000$} & $\$ 45,000$ & $\begin{array}{l}3 \text { Fan Coil Units for other spaces (game } \\
\text { room, laundry, misc) (Larger for RHC } \\
\text { system due to } 60^{\circ} \mathrm{F} \text { CHWS temps) }\end{array}$ \\
\hline & $\$ 12,000$ & $\begin{array}{l}\text { Indirect evap cooler related } \\
\text { controls/monitoring }\end{array}$ \\
\hline$\$ 18,000$ & $\$ 18,000$ & $\begin{array}{l}\text { Heating/cooling switchover controls - } \\
\text { dynamic - load based }\end{array}$ \\
\hline$\$ 30,000$ & $\$ 30,000$ & $\begin{array}{l}\text { Exhaust system modifications in rooms } \\
\text { - add manual dampers }\end{array}$ \\
\hline \multirow[t]{2}{*}{$\$ 6,000$} & $\$ 6,000$ & $\begin{array}{l}\text { Exhaust system modifications at roof - } \\
1 \mathrm{EF} / \text { controls }\end{array}$ \\
\hline & $\$ 64,800$ & $\begin{array}{l}\text { Insulate existing make-up air duct - re- } \\
\text { use for DOAS distribution }\end{array}$ \\
\hline
\end{tabular}




\begin{tabular}{|c|c|c|}
\hline$\$ 30,000$ & $\$ 30,000$ & $\begin{array}{l}\text { Ducting in rooms for DOAS - Radiant } \\
\text { to diffuser }\end{array}$ \\
\hline$\$ 50,400$ & & Create closets for Fan Coil Units \\
\hline \multirow[t]{2}{*}{$\$ 86,400$} & & Install Fan Coil Unit access doors \\
\hline & $\$ 40,000$ & $\begin{array}{l}\text { DOAS AHU Controls/monitoring } \\
\text { equipment }\end{array}$ \\
\hline$\$ 17,000$ & $\$ 17,000$ & $\begin{array}{l}\text { Automatic Heating/Cooling switchover } \\
\text { valves and controls }\end{array}$ \\
\hline \multirow[t]{8}{*}{$\$ 4,320$} & $\$ 4,320$ & New room supply air diffusers \\
\hline & $\$ 25,000$ & Toilet exhaust system heat recovery \\
\hline & $\$ 24,000$ & $\begin{array}{l}\text { Radiant heating/cooling (RHC) room } \\
\text { controls/DDC thermostat heating and } \\
\text { cooling - switchover }\end{array}$ \\
\hline & $\$ 8,000$ & RHC water temp mixing controls \\
\hline & $\$ 20,000$ & $\begin{array}{l}\text { RHC circulating pump system and } \\
\text { VFD/controls }\end{array}$ \\
\hline & $\$ 94,400$ & RHC panels system \\
\hline & $\$ 38,800$ & $\begin{array}{l}\text { RHC attachment to ceiling (provide } \\
\text { ceiling for third floor) }\end{array}$ \\
\hline & $\$ 400,000$ & $\begin{array}{l}\text { RHC piping to each unit (larger than } \\
\text { existing piping) }\end{array}$ \\
\hline$\$ 458,200$ & & $\begin{array}{l}144 \text { two-pipe FCUs (nominal } 1 / 2 \text { ton } \\
\text { each, derated to use } 50^{\circ} \mathrm{F} / 68^{\circ} \mathrm{F} \\
\text { CHWS/CHWR temperatures) }\end{array}$ \\
\hline$\$ 400,000$ & & Piping to FCUs \\
\hline$\$ 338,400$ & & DDC controls for FCUs \\
\hline$\$ 1,526,720$ & $\$ 1,025,320$ & Subtotal \\
\hline$\$ 152,672$ & $\$ 102,532$ & Mech Contractor Overhead @10\% \\
\hline$\$ 152,672$ & $\$ 102,532$ & Mech Contractor Profit @10\% \\
\hline$\$ 152,672$ & $\$ 102,532$ & General Contractor Fee @ $10 \%$ \\
\hline$\$ 1,984,736$ & $\$ 1,332,916$ & Subtotal, hard costs \\
\hline$\$ 317,558$ & $\$ 213,267$ & COE Admin@16\% \\
\hline$\$ 198,474$ & $\$ 133,292$ & Mech Engineering @10\% \\
\hline$\$ 59,542$ & $\$ 39,987$ & Elec Engineering @ 3\% \\
\hline$\$ 59,542$ & $\$ 39,987$ & Controls Engineering @ 3\% \\
\hline$\$ 19,847$ & $\$ 13,329$ & Struct Engineering@1\% \\
\hline$\$ 99,237$ & $\$ 66,646$ & Constr Management@5\% \\
\hline$\$ 99,237$ & $\$ 66,646$ & Proj Management @ 5\% \\
\hline$\$ 59,542$ & $\$ 39,987$ & $\begin{array}{l}\text { Travel related expenses, all disciplines } \\
\text { @ } 3 \%\end{array}$ \\
\hline$\$ 138,932$ & $\$ 93,304$ & $\begin{array}{l}\text { Commissioning (all onsite, no remote) } \\
\text { (a) } 7 \%\end{array}$ \\
\hline$\$ 1,051,910$ & $\$ 706,445$ & Subtotal, soft costs \\
\hline$\$ 3,036,646$ & $\$ 2,039,361$ & Project Subtotal \\
\hline$\$ 455,497$ & $\$ 305,904$ & Unseen conditions multiplier @ 15\% \\
\hline$\$ 455,497$ & $\$ 305,904$ & $\begin{array}{l}\text { Project escalation due to future } \\
\text { installation date @ } 15 \%\end{array}$ \\
\hline$\$ 455,497$ & $\$ 305,904$ & Remote site multiplier@15\% \\
\hline$\$ 4,403,137$ & $\$ 2,957,074$ & System Total \\
\hline
\end{tabular}

Perhaps surprisingly, the Fort Irwin Option 2 system (DOAS, radiant heating/cooling, direct/indirect evaporative cooling) is estimated to be significantly less expensive to install than the conventional HVAC system using fan coil units and makeup air units. Although this Option 2 system is not identical to the system simulated in our modeled barracks facility, it is sufficiently similar to suggest that the "improved" version of the modeled facility (DOAS with radiant heating and cooling) should be a less costly alternative than the conventional HVAC system it replaced. That being the case, the "improved" system is the obvious choice for the modeled barracks facility since it not only has a lower first cost but also superior energy performance.
Table 7. Comparison of estimated retrofit costs common to both systems

\begin{tabular}{|c|c|c|}
\hline $\begin{array}{c}\text { Typical } \\
\text { Upgrade } \\
\text { Project }\end{array}$ & $\begin{array}{c}\text { Option } 2 \\
\text { Approach }\end{array}$ & Other Common Work Elements \\
\hline$\$ 91,000$ & $\$ 200,000$ & R-40 roof insulation \\
\hline$\$ 79,000$ & $\$ 79,000$ & R-18 Wall insulation \\
\hline$\$ 107,000$ & $\$ 107,000$ & Double Pane, Low E, Operable windows \\
\hline$\$ 277,000$ & $\$ 386,000$ & Subtotal \\
\hline$\$ 27,700$ & $\$ 38,600$ & General Contractor Fee - Army @ 10\% \\
\hline$\$ 304,700$ & $\$ 424,600$ & Subtotal, hard costs \\
\hline$\$ 48,752$ & $\$ 67,936$ & COE Administration@16\% \\
\hline$\$ 3,047$ & $\$ 4,246$ & Mechanical Engineering@1\% \\
\hline$\$ 15,235$ & $\$ 21,230$ & Electrical Engineering@5\% \\
\hline$\$ 9,141$ & $\$ 12,738$ & Controls Engineering @ 3\% \\
\hline$\$ 9,141$ & $\$ 12,738$ & Structural Engineering @3\% \\
\hline$\$ 15,235$ & $\$ 21,230$ & Construction Management @ 5\% \\
\hline$\$ 15,235$ & $\$ 21,230$ & Project Management@ @ 5\% \\
\hline$\$ 9,141$ & $\$ 12,738$ & $\begin{array}{l}\text { Travel related expenses, all disciplines @ } \\
3 \%\end{array}$ \\
\hline$\$ 15,235$ & $\$ 21,230$ & $\begin{array}{l}\text { Commissioning (all onsite, no remote) @ } \\
5 \%\end{array}$ \\
\hline$\$ 140,162$ & $\$ 195,316$ & Subtotal, soft costs \\
\hline$\$ 444,862$ & $\$ 619,916$ & Project Subtotal \\
\hline$\$ 66,729$ & $\$ 92,987$ & Unseen conditions multiplier @ 15\% \\
\hline$\$ 66,729$ & $\$ 92,987$ & $\begin{array}{l}\text { Project escalation due to future } \\
\text { installation date @ } 15 \%\end{array}$ \\
\hline$\$ 66,729$ & $\$ 92,987$ & Remote site multiplier @ 15\% \\
\hline$\$ 645,050$ & $\$ 898,878$ & System Total \\
\hline $\begin{array}{l}\text { Base } \\
\text { Case }\end{array}$ & $\$ 253,828$ & $\begin{array}{l}\text { Incremental Cost Difference for Net-Zero } \\
\text { Energy Facility Modifications }\end{array}$ \\
\hline
\end{tabular}

Having established that, for a major barracks upgrade project, replacing the conventional HVAC system with an "improved" system is a better investment than replacing the existing conventional HVAC system with a similar system, one should consider whether to "further improve" the facility with an enhanced building envelope.

After completion of a Barracks Upgrade project, barracks facilities have an envelope air leakage rate of approximately $0.4 \mathrm{CFM} / \mathrm{ft}^{2}$ at $0.3 \mathrm{iwg}(75 \mathrm{~Pa})$. From our experience, we have found that further reducing the leakage rate to $0.25 \mathrm{CFM} / \mathrm{ft}^{2}$ at $0.3 \mathrm{iwg}(75 \mathrm{~Pa})$ can be accomplished for about $\$ 0.50 / \mathrm{ft}^{2}\left(\$ 5.38 / \mathrm{m}^{2}\right)$. For the barracks facilities, this would add about $\$ 12,000$ to the project costs which is about $0.37 \%$ of the total project cost.

By studying Fig. 17, one can compare the $\$ 12,000$ additional cost of "further improving" the building envelope to $0.25 \mathrm{CFM} / \mathrm{ft}^{2}$ at $0.3 \mathrm{iwg}(75 \mathrm{~Pa})$ with the additional simulated annual energy savings of making this improvement. For Fairbanks, AK, for example, the additional annual energy savings of further tightening the building envelope of a barracks facility is about $\$ 5000$, yielding a simple payback of this further improvement to be less than 2.5 years. Warmer climate locations are not expected to yield such short payback periods. 
Similar cost estimates were not performed for the simulated administration facility, so no effort will be made to provide a detailed discussion of the economic payback of a project to "improve" or "further improve" such facilities. Nevertheless, given that the cost estimate for upgrading the barracks facilities indicates that the DOAS with radiant heating/cooling and direct/indirect evaporative cooling should be less expensive than the traditional barracks upgrade project, it seems reasonable to expect that this may also be true for a major upgrade of an administration facility.

\section{CONCLUSIONS}

Retrofit of existing buildings with innovative technologies may not be economically viable if one is contemplating a project primarily for the sake of energy conservation. However, if a major renovation project is being planned, one should compare the delta (premium) costs of advanced technologies against the additional energy efficiency realized by the advanced technologies versus the costs and energy performance of conventional retrofit technologies. In many cases, this analysis will demonstrate the wisdom of investing a bit more money in more advanced technologies in order to realize substantial energy cost savings.

In this study, incorporating innovative technologies into major facility upgrade projects was shown to have potential for significant energy performance improvements and may actually cost less than conventional "tried and true" approaches. For example, DOAS systems, when combined with radiant heating/cooling systems and tight building envelopes have significant potential to economically save energy while maintaining comfort. Depending on location, additional sealing of the building envelope may also be cost effective.

\section{REFERENCES}

[1] ASHRAE (1989). ANSI/ASHRAE/IESNA

Standard 90.1-1989 Energy Efficient Design of New

Buildings except Low-Rise Residential Buildings. Atlanta, GA: American Society of Heating, Refrigerating and AirConditioning Engineers, Inc.

[2] Briggs, R.S., Lucas, R.G., and Taylor, T.; Climate Classification for Building Energy Codes and Standards: Part 2 - Zone Definitions, Maps and Comparisons, Technical and Symposium Papers, ASHRAE Winter Meeting, Chicago, IL, January, 2003.

[3] ASHRAE (2007). ANSI/ASHRAE Standard 62.12007, Ventilation for Acceptable Indoor Air Quality, Atlanta, GA: American Society of Heating, Refrigerating and Air-Conditioning Engineers, Inc.

[4] Jeong, J-W., Mumma, S.A. "Designing a Dedicated Outdoor Air System with Ceiling Radiant Cooling Panels", ASHRAE Journal, pp. 56-66, October 2006.
[5] Mumma, S.A. "Chilled Ceilings in Parallel with Dedicated Outdoor Air Systems: Addressing the Concerns of Condensation, Capacity, and Cost", ASHRAE Transactions 2002, Vol 108, Part 2, pp. 220-231.

[6] Underwood, David M., Zhivov, A., Duncan, S., Woody, A., Björk, C., Richter, S., Neth, D., Pinault, D., Jank, R. "Working Towards Net Zero Energy at Fort Irwin", draft ERDC-CERL technical report. 


\section{REPORT DOCUMENTATION PAGE}

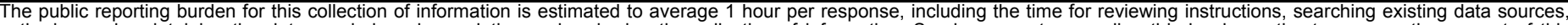

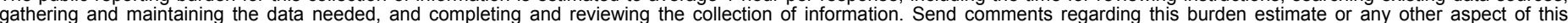

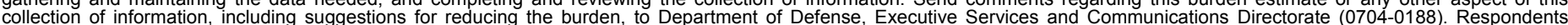

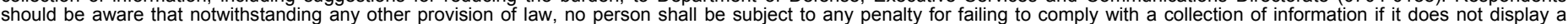

should be aware that notwithstandin

PLEASE DO NOT RETURN YOUR FORM TO THE ABOVE ORGANIZATION.

\begin{tabular}{l|l|l|l} 
1. REPORT DATE (DD-MM-YYYY) & 2. REPORT TYPE & 3. DATES COVERED (FrOm - TO)
\end{tabular}

August 2010

Conference Paper

4. TITLE AND SUBTITLE

Practical Integration Approach and Whole Building Energy

Simulation of Three Energy Efficient Building Technologies: Preprint

5a. CONTRACT NUMBER

DE-AC36-08-GO28308

5b. GRANT NUMBER

5c. PROGRAM ELEMENT NUMBER

6. AUTHOR(S)

J.P. Miller, M. Deru, K. Benne, A. Zhivov, and D. Heron

5d. PROJECT NUMBER

NREL/CP-550-48125

5e. TASK NUMBER

WF5N1000

5f. WORK UNIT NUMBER
7. PERFORMING ORGANIZATION NAME(S) AND ADDRESS(ES)

National Renewable Energy Laboratory

1617 Cole Blvd.

Golden, CO 80401-3393

9. SPONSORING/MONITORING AGENCY NAME(S) AND ADDRESS(ES)
8. PERFORMING ORGANIZATION REPORT NUMBER

NREL/CP-550-48125
10. SPONSOR/MONITOR'S ACRONYM(S) NREL

11. SPONSORING/MONITORING AGENCY REPORT NUMBER

12. DISTRIBUTION AVAILABILITY STATEMENT

National Technical Information Service

U.S. Department of Commerce

5285 Port Royal Road

Springfield, VA 22161

13. SUPPLEMENTARY NOTES

14. ABSTRACT (Maximum 200 Words)

Three technologies that have potential to save energy and improve sustainability of buildings are dedicated outdoor air systems, radiant heating and cooling systems and tighter building envelopes. To investigate the energy savings potential of these three technologies, whole building energy simulations were performed for a barracks facility and an administration facility in 15 U.S. climate zones and 16 international locations.

\section{SUBJECT TERMS}

dedicated outdoor air system; radiant heating; radiant cooling; building envelope

\begin{tabular}{|c|c|c|}
\hline $\begin{array}{l}\text { a. REPORT } \\
\text { Unclassified }\end{array}$ & $\begin{array}{l}\text { b. ABSTRACT } \\
\text { Unclassified }\end{array}$ & $\begin{array}{l}\text { c. THIS PAGE } \\
\text { Unclassified }\end{array}$ \\
\hline
\end{tabular}

\begin{tabular}{l|l|} 
17. LIMITATION \\
OF ABSTRACT \\
UL
\end{tabular}

19a. NAME OF RESPONSIBLE PERSON

19b. TELEPHONE NUMBER (Include area code) 